\title{
Testing the role of screening with vocational skills: the case of post-secondary initial vocational training institutes in Greece
}

\author{
Constantinos Tsamadias ${ }^{a}{ }^{*}$ and Stefanos Chanis ${ }^{b}$ \\ ${ }^{a}$ Harokopio University, Athens, Greece, ${ }^{b}$ Piraeus University, Piraeus, Greece
}

\begin{abstract}
The paper examines whether post secondary initial vocational training acts as a filter in the private sector segment of the Greek labour market, using a sample consisting of post secondary initial vocational training graduates and secondary education graduates (control group). The results suggest that no screening is evident in the case of male employees, whereas the hypothesis of «weak» screening cannot be rejected in the case of female employees.
\end{abstract}

Keywords: initial vocational training, human capital, screening hypothesis

\section{Introduction}

According to the human capital literature (Schultz, 1961; Becker, 1964; Mincer, 1974), education and training are the main channels of producing, accumulating and diffusing human capital. According to human capital theory (Schultz, 1961; Becker 1964), education and training enhance productivity and lead to higher earnings and wages. Alternatively, according to the screening hypothesis, employers use education and training to find the workers with greater ability in a pool of job applicants whose qualities are uncertain. Screenists argue that education and training serve as a filter for individuals' abilities and are not a productivity enhancing mechanism (Berg, 1971; Arrow, 1973; Spence, 1973; Stiglitz, 1975).

More than 35 years have passed since the screening hypothesis has first gained attention, and yet, much is still unknown about the relative importance of the screening hypothesis compared to human capital theory. Following the seminal study (Arrow, 1973), testing the screening hypothesis has remained a popular research topic in the economics of education. One particular method of testing the screening hypothesis is to evaluate the distinction between the «strong» and the «weak» version of the screening hypothesis. According to the «strong» version, employers continue to pay higher wages to the more educated or trained, even after the employee has

* Corresponding author: Constantinos Tsamadias, Harokopio University, Athens, Greece, ctsamad@ hua.gr. We would like to thank Emmanuel Mamatzakis and especially George Psacharopoulos for their insightful comments on this paper. 
been with them for some time. According to the «weak» version, employers offer higher starting salaries to more educated or trained employees relative to the less educated or trained in the absence of any other information on the new employees' expected productivities. But if education or training were really used as a screening device and the more educated or trained were not more productive relative to their less educated or trained counterparts, employers would adjust downwards the initial wage premim they offered. Or, the observed experience-earnings profiles of employees with different levels of education or training would converge rather than diverge, over time.

This paper tests both the «strong» version and the «weak» version of the screening hypothesis. The data come from a sample based on a survey conducted by the authors. This sample consists of selected private Greek enterprises and provides data on both post-secondary initial vocational training (PSIVT) graduates and secondary education graduates, who act as the control group.

The paper is organised as follows. In Section 2, we summarise the screening literature. Section 3 presents a brief background on the post-secondary initial vocational training system, and Section 4 outlines the sampling methodology and the data. In Section 5, we report results from the empirical analysis, and in Section 6, we conclude.

\section{Literature review}

There is strong empirical evidence of the positive relationship between education or training and wages (Willis, 1986; Murphy \& Welch, 1990). These empirical findings, as is often the case with empirical research, are not unchallenged. Two contrasting views have emerged in recent decades. Human capital theory argues that education and training directly augment individual productivity by enhancing the cognitive, behavioural and manual capacities of individuals, thereby increase wages and earnings (Mincer, 1974; Becker, 1975). In contrast, according to the screening hypothesis, education and training are merely indicators of ability (Arrow, 1973; Spence, 1973; Stiglitz \& Weiss, 1975). This hypothesis assumes that individuals hold different levels of productivity from birth. Thus, education and training merely signal inherent productivity without contributing to productivity. More capable individuals invest in education and training to signal their higher abilities, and employers use education and training to select more able individuals in the absence of better information. However, education and training do not contribute to productivity. In short, human capital theory holds that the economic value of education is productive, while the screening hypothesis argues for the informative value of education. $\mathrm{Hu}-$ man capital theory and the screening hypothesis are the two elementary, competitive and complementary theories in the economics of education. They both explain the positive relationship between education and earnings (Li et al., 2009).

Another approach has been proposed that contrasts a «strong» and a «weak» version of the screening hypothesis. This approach addresses a theoretical distinction between the «weak» and the «strong» version of the screening hypothesis, depend- 
ing on whether employers pay irrational wages at the initial hiring point («weak») or continuously («strong») (Psacharopoulos, 1979).

If employers have limited information on ability, they might use education or training as an initial filter («weak» screening), but as these employers accumulate direct evidence on the productivity of workers on the job, the employers will cease using education or training as a filter to determine promotions and pay increases. Under strong screening, except when employers do not observe productivity directly, as employees accumulate experience, employers will continue to pay more for education or training as a signal of ability. In the case of «weak» screening, the earnings premium associated with education or training should decline with experience, whereas in the case of «strong» screening, this decline should not occur. Psacharopoulos (1979) reported that the wage differential associated with experience was higher in the distributive trades, which are assumed to be a competitive sector without «strong» screening, than in public administration, rejecting the hypothesis that «strong» screening might persist in non-competitive sectors. The «weak» screening hypothesis, alternately, concedes that while the primary role of education and training is to produce a signal, education may additionally augment inherent productivity. The «strong» screening hypothesis presumes that productivity is immutable and that education and training are used exclusively as a signal.

A number of empirical studies designed to test the validity of the screening hypothesis have employed various data sets, methodologies and techniques but have reported contradictory results (Taubman \& Wales, 1973; Layard \& Psacharopoulos, 1974; Wiles, 1974; Wolpin, 1977; Psacharopoulos, 1979, 1983; Riley, 1976, 1979; Lee, 1980; Katz \& Ziderman, 1980; Albrecht, 1981; Fredland \& Little, 1981; Liu \& Wong, 1982; Miller \& Volker, 1983; Tucker, 1985, 1986; Cohn et al., 1986, 1987; Arabsheibani, 1989; Ziderman, 1992; Oosterbeek, 1992; Groot \& Oosterbeek, 1994; Brown \& Sessions, 1999; Bedard, 2001; Riley, 2001; Spence, 2002; Heywood \& Wei, 2004; Miler, Mulvey \& Martin, 2004; Miler, 2009; Li et al., 2009).

So far, only a few studies on the screening hypothesis have focused on Greece (Lambropoulos, 1992; Magoula \& Psacharopoulos, 1999; Psacharopoulos \& Tsamadias, 2001).

\section{The Greek post-secondary initial vocational training system}

In Greece, the system of lifelong learning operates in parallel with the formal educational system. The basic component of lifelong learning is the training system (law 3369/2005). The training system consists of initial training and continuing training. Table 1 shows the structure of the educational system.

The educational system, especially the secondary level of education, provides general skills with a particular emphasis on humanities. Thus, the educational system does not intensively contribute to the acquisition of practical or vocational skills. The structure of the formal initial training system (post-compulsory and post-secondary) is summarised in Table 2 (law 1992). 
Table 1: The structure of the Greek formal educational system (2008-2009)

\begin{tabular}{|c|c|c|c|c|}
\hline Levels & $\begin{array}{l}\text { Duration } \\
\text { of studies }\end{array}$ & Age & ISCED $^{*}$ & $\begin{array}{l}\text { Compulsory or } \\
\text { non-compulsory }\end{array}$ \\
\hline \multicolumn{5}{|l|}{ Post-graduates studies } \\
\hline Ph.D. & 3 years & $\geq 24$ & \multirow{2}{*}{ Level 6} & \multirow{2}{*}{ Non- compulsory } \\
\hline Master's degree & 2 years & $\geq 22$ & & \\
\hline \multicolumn{5}{|l|}{ Higher education } \\
\hline Universities & $4-6$ years & $\geq 18$ & \multirow{2}{*}{ Level 5} & \multirow{2}{*}{ Non- compulsory } \\
\hline Technological education institutions & 4 years & & & \\
\hline \multicolumn{5}{|l|}{ Secondary education } \\
\hline Upper (higher) secondary education [lyceum] & 3 years & $15-17$ & \multirow[t]{2}{*}{ Level 3} & Non- compulsory \\
\hline Technical-vocational school & 2 years & $15-16$ & & Non- compulsory \\
\hline Lower secondary education [gymnasium] & 3 years & $12-14$ & Level 2 & Compulsory \\
\hline \multicolumn{5}{|l|}{ Primary education } \\
\hline Primary (elementary) school & 6 years & $6-11$ & Level 1 & Compulsory \\
\hline \multicolumn{5}{|l|}{ Pre-school education ${ }^{* *}$} \\
\hline Nursery school & & $4-5$ & Level 0 & Non-compulsory \\
\hline
\end{tabular}

* International Standard Classification for Education (ISCED, 1997) prepared by UNESCO

** Compulsory since 2010-2011

Table 2: The structure of the Greek formal initial training system (2008-2009)

\begin{tabular}{lcccc}
\hline Levels & $\begin{array}{c}\text { Duration } \\
\text { of training }\end{array}$ & Age & ISCED $^{*}$ & Compulsory \\
\hline $\begin{array}{l}\text { Post-secondary level } \\
\text { Initial vocational training institutes }\end{array}$ & 2 years & $\geq 18$ & Level 4 & No \\
Post-compulsory level & 2 years & $\geq 15$ & Level 4 & No \\
Initial vocational training institutes & 2 & & & \\
\hline
\end{tabular}

* International Standard Classification for Education (ISCED, 1997) prepared by UNESCO

The initial vocational training system is supervised by the Ministry of Education (MoE) and is mainly offered by both the public and private vocational training institutes (I.E.K.s). However some I.E.K.s are under the supervision of other ministries and agencies. The I.E.K.s provide all types of vocational training and ensure that students obtain all necessary qualifications by imparting scientific, technical, vocational and practical knowledge and cultivating skills to facilitate students' occupational integrations and adaptations to the changing needs of the production process. Graduates of compulsory education may enrol in the post-compulsory I.E.K.s, and 
the graduates of every type of lyceum and technical vocational schools (T.E.E.s) may enrol in the post-secondary I.E.K.s. The duration of training for the unified lyceum certificate holders is four semesters. Each training year consists of two selfcontained semesters. T.E.E. or technical vocational lyceum (T.E.L.) cycle 2 certificate holders are directly admitted to the third semester of the I.E.K. in their specialisation area (total duration of study: one year), or they may choose another I.E.K. specialisation area, in which case they study for the regular module of four semesters. Certain I.E.K.s accepts gymnasium graduates over 18 years of age, who may study for up to two semesters. During the terms, the students attend compulsory theoretical, laboratory and mixed classes in the framework of the educational curricula, which cover a wide range of branches and specialisations in the following fields: Information Technology-Telecommunications-Networks, Financial and Management Services, Food and Drink, Transport and Tourism, Electronics-ElectricsEngineering, Construction, Industrial Chemistry, Applied Arts, Energy-Environment, Health-Cosmetics-Social Services, Communications and Mass Media, Clothing and Footwear, Culture and Sport and Agriculture. Students in public I.E.K.s are charged fees for each semester. Scholarships are available in certain circumstances. In addition, students have the opportunity to participate in subsidised practical exercises. The fees charged by the private I.E.K.s vary and are adjusted each year in accordance with the current regulations. Trainees who successfully complete their training in public and private I.E.K.s are awarded a vocational training certificate, which allows them to take the qualifying examinations leading to the award of a vocational training diploma at the level of post-secondary $(3+)$ vocational training. Nationwide examinations, held twice a year, include theoretical and practical tests. Adult gymnasium (Secondary chance school) graduates who study at the I.E.K.s' post-gymnasium departments sit for qualifying examinations to obtain a vocational training diploma, level 1. Before taking the qualifying examinations for the vocational training certificate, graduates may attend an optional six-month practical training course, which is considered a period of service for obtaining a licence to be qualified at an occupation. This training is provided by the public sector or by private firms and is supervised by a coordinator. The vocational training diploma is recognised both in Greece and in the other EU countries and is a prerequisite for obtaining a licence to be a member of a profession in the relevant specialisations. Links with firms are scarce, and there is no formal way to absorb and channel graduates into the labour market.

\section{Sources and data}

The current survey, which was conducted in the first semester of 2010, collected annual earnings from the year 2009 from the hired labour of I.E.K.s and S.E. graduates (control group). The questionnaires were collected from I.E.K.s and S.E. graduates who do not have any additional education or training and have full time work. Productivity bonuses are included in the annual earnings. Earnings from overtime are 
not included. Self-employed I.E.K.s and S.E. graduates are not included because it is difficult to separate the income from self-employment from income from other factors in the production process. Part-time employees are additionally excluded.

The sample was collected from 58 randomly selected, private enterprises located in Greek regions. In particular, 19 private enterprises were located in Attica, 15 in Central Macedonia, 14 were located in the other regions of continental Greece, and finally, 10 private enterprises were located in the North and South Aegean, Ionian Islands and Crete. Two of the private enterprises were in the primary sector, 23 were in the secondary sector, and 33 were in the tertiary sector. Of the 58 private enterprises, 14 were large (more than 100 employees), and 44 were small or medium size (under 100 employees).

In the public sector, the earnings of I.E.Ks. and S.E. graduates are the same (law $3205 / 2003$ ). We tested the application of the law in two ministries, five municipalities and five other public entities. The tests show that the law has been applied.

Our sample is divided into two sub-samples. Sub-sample I include I.E.K.s graduates who have full-time employment in the private sector, and sub-sample II consists of a control group of S.E. graduates who work as full time employees in the private sector.

The sample has been stratified with a proportional distribution. The stratified sampling not only provides increased accuracy but also allows separate estimates for each stratum. The proportional distribution is the most commonly used method of sampling by strata. This procedure happens in the absence of information on the homogeneity of the strata to ensure a representative sample (Zairis, 1991).

At the beginning of this project, a pilot sample of 135 observations (80 S.E. graduates and 55 I.E.K.s graduates) was collected.

The minimum size of each stratum of the sample is determined using the following formula:

$n_{0}=\frac{\Sigma W_{h} S_{h}^{2}}{\bar{Y}^{2}} \frac{C V_{0}^{2}\left(\bar{y}_{A N}\right)}{C}$

Where the standard error SE is estimated using the formula:

$S E(\bar{y})=C V^{*} \bar{Y}$

Where $W_{h}$ is the weight of each stratum in the population,

$S_{h}^{2}$ is the variance of each stratum,

$\bar{Y}$ is the mean gross earnings (from the pilot sample) and

$C V_{0}^{2}\left(\bar{y}_{A N}\right)$ is the desired coefficient of variation. 
We note that, using the pilot sample, we calculated the mean earnings as 15.545 euros per year. The $C V_{0}$ was defined at $0.01(1 \%)$

Table 3 presents the structure of the total population and the sample by employment sector and level of education or training.

Table 3: Structure of the population and the sample by level of education or training and sector of employment, 2009

\begin{tabular}{lccc}
\hline \multirow{2}{*}{ Educational or training levels } & \multicolumn{2}{c}{ Population (per cent) } & Sample \\
\cline { 2 - 3 } & Public sector & Private sector & Private sector \\
\hline S.E. graduates & 27.53 & 72.47 & 1,400 \\
I.E.K. graduates & 26.36 & 73.64 & 462 \\
\hline
\end{tabular}

Source: Labour Force Survey, Statistical Service of Greece (NSSG, 2009)

\section{Post-secondary initial vocational training as a filter}

Table 4 presents the sample mean earnings of employees in the private sector in Greece for the year 2009, by level of education or training and by gender.

Table 4: Mean annual earnings by level of education or training and gender (in Euros, 2009)

\begin{tabular}{lcccccc}
\hline \multicolumn{7}{c}{ Employees in the private sector } \\
\hline $\begin{array}{l}\text { Educational or training } \\
\text { levels }\end{array}$ & \multicolumn{7}{c}{ Mean gross earnings } & N & Males & Females \\
\hline S.E. graduates & 16,312 & 18,023 & 13,752 & 1,400 & 839 & 561 \\
I.E.K.s graduates & 17,252 & 19,273 & 15,524 & 462 & 213 & 249 \\
All & 16,545 & 18,276 & 14,297 & 1,862 & 1,052 & 810
\end{tabular}

Note: $\mathrm{N}$ is the number of observations

A detailed earnings distribution by age and experience is given in Tables A-1 and A-2 (available from the authors on request). The mean earnings of I.E.K.s graduates are about $5.76 \%$ higher than those of S.E. graduates. More specifically, the male earnings premium is approximately $6.93 \%$, while the female earnings premium is approximately $12.88 \%$. These findings are in accord with human capital theory and the findings of empirical work conducted in Greece and abroad (Psacharopoulos \& Tsamadias, 2001). In the public sector, there are no differences on earnings between I.E.K.s and S.E. graduates. 
There are several methods to estimate the returns to private and social investment in education and training (Psacharopoulos \& Patrinos, 2002). In this paper, we use the Mincerian method.

The private rate of return has been estimated by the formula:

$L n Y_{i}=a+b \cdot S_{i}+c \cdot E X_{i}+d \cdot E X_{i}^{2}+u_{i}$

Where $Y_{i}$ is gross annual earnings, $S_{i}$ is years of study, $E X_{i}$ is experience (number of years), $a$ is a constant, $u_{i}$ is the disturbance term and $b, c$ and $d$ are the regression coefficients.

Table 5: Estimates of the basic function using gross earnings and actual experience

\begin{tabular}{lcc}
\hline \multirow{2}{*}{ Independent Variables } & \multicolumn{2}{c}{ Dependent variable (LnYg) } \\
& Males & Females \\
\hline a (constant) & $8.465^{* *}$ & $8.141^{* *}$ \\
& $(50.03)$ & $(50.28)$ \\
S & $0.0460^{* *}$ & $0.0567 * *$ \\
& $(3.46)$ & $(4.44)$ \\
EX & $0.0552^{* *}$ & $0.0555^{* *}$ \\
& $(12.42)$ & $(11.37)$ \\
EX ${ }^{2}$ & $-0.00064^{* *}$ & $-0.00062^{* *}$ \\
Adj. $\mathrm{R}^{2}$ & $(-5.49)$ & $(-4.36)$ \\
F & 0.4181 & 0.4538 \\
Significance & 252.75 & 225.04 \\
$\mathrm{~N}$ & 0.0000 & 0.0000 \\
\hline
\end{tabular}

Note: ** Significance at the $5 \%$ level

Table 6: The private rate of return (in per cent) using the Mincerian method

\begin{tabular}{lc}
\hline Gender & Rate of return \\
\hline Males & 4.60 \\
Females & 5.67
\end{tabular}

The private rates of return for the public sector employees are zero because the earnings of the I.E.K.s and S.E. graduates are similar. Therefore, the returns to training in the private sector are higher than the corresponding returns in the public sector. This difference means that private employers value training and pay a premium for it, hence rejecting the hypothesis that training is only used as a screening device. Moreover, these low returns indicate why there is such a relative low demand for post-secondary initial vocational training in Greece. 
Figure 1 shows the mean gross annual earnings by years of experience, education or training levels and gender.

Figure 1: Mean gross annual earnings by years of experience, education or training levels and gender (in Euro)

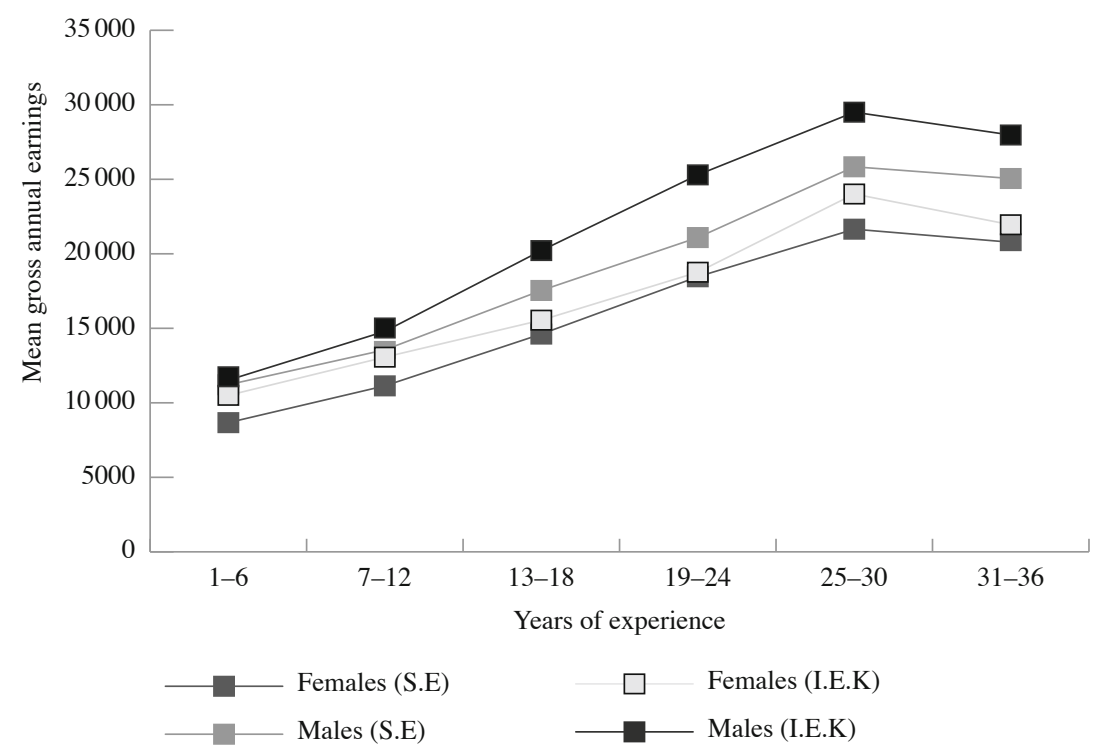

The initial earnings advantage of the I.E.K.s graduates compared with the S.E. graduates (control group) is maintained at a constant level of about 5.76\% throughout employees' careers. This advantage is higher in the private sector than in the public sector. Furthermore, it is also higher for females (12.88\%) than males $(6.93 \%)$.

Figure 2 shows the earnings ratios by years of actual experience for private sector workers. 
Figure 2: Earnings ratios by years of experience (private sector workers)

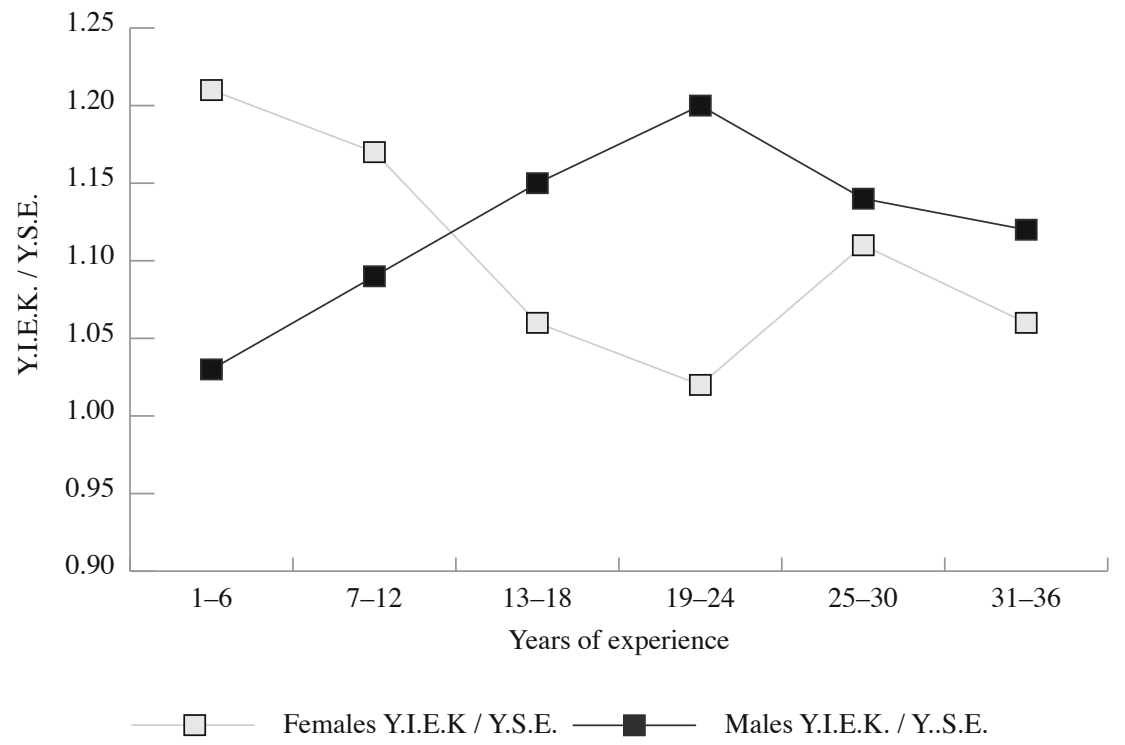

A more elaborate test explores the «weak» versus the «strong» version of the screening hypothesis. According to the «weak» version, employers could initially offer higher wages to the more educated or trained workers because of the absence of information on their prospective productivity. However, if education or training was indeed used as a screening device, and the more educated or trained were not more productive than their less educated or trained counterparts, private employers would adjust the initial wage premium downwards. That is, the observed experience-earnings profiles of people with different levels of education and training would converge, rather than diverge, over time. We narrow the test to include post-secondary initial vocational training versus secondary education. Thus, we included in our analysis only employees from the private sector of the economy to conduct a more rigorous test of the non-convergence of experience-earnings profiles with an interaction term as follows:

$L n Y_{i}=a+b^{*} S_{i}+c^{*} E X_{i}+d \cdot\left(S_{i}^{*} E X_{i}\right)+u$

Where $Y_{i}$ is gross annual earnings, $S_{i}$ is years of study and $E X_{i}$ is experience in years.

Data were analysed based on actual experience and not on potential experience. The actual experience was derived from the sampling, while the potential experience data were derived using the Mincerian definition of experience (i.e., age minus years of education and training minus compulsory school entrance age). Potential experi- 
ence might not accurately reflect true experience, particularly for females, because of their absence in the labour market for child-bearing and family reasons. $S_{i}{ }^{*} E X_{i}$ is an interaction term, $a$ is a constant, $b, c$ and $d$ are the regression coefficients, and $u$ is the disturbance term. The sign of the coefficient $d$ and its statistical significance determine whether filtering occurs. Thus, $a$ positive and significant $d$ would indicate divergence of the two profiles, while $a$ negative and significant $d$ would indicate convergence of the two profiles, lending support to the screening hypothesis. To improve the precision of the test, we have fit the above function separately for males and females. Table 7 presents a test for the sign and significance of the $S^{*} E X$ interaction term.

Table 7: Testing for the screening hypothesis (dependent variable: LnYG)

\begin{tabular}{lcc}
\hline Independent variables & \multicolumn{2}{c}{ With actual experience } \\
\hline$\alpha$ (constant) & Males & Females \\
S & $9,043626^{* *}$ & $7,283204 * *$ \\
& $(-26,13)$ & $(-21,83)$ \\
EX & 0,012298 & $0,1350051^{* *}$ \\
& $(-0,44)$ & $(-5,08)$ \\
S*EX & 0,0035548 & $0,0982894 * *$ \\
Adj. $\mathbf{R}^{2}$ & $(-0,18)$ & $(-4,89)$ \\
F & 0,0022816 & $-0,0050331^{* *}$ \\
Significance & $(-1,46)$ & $(-3,15)$ \\
$\mathrm{N}$ & 0,403 & 0,45 \\
\hline
\end{tabular}

The explanatory power of the model, Adj. $\mathrm{R}^{2}$, fluctuates from $40.3 \%$ to $45.0 \%$. This level of fluctuation is satisfactory, given that we use cross-sectional data. In particular, the t-statistic is satisfactory. Splitting the sample by gender, for males, the critical interaction term, coefficient $d$, is positive but not stastistical significant, while for females $d$ is negative and significant at the 5\% level. These results indicate that for the male sub-sample, there is not a significant increase of earnings by years of experience, hence rejecting the screening hypothesis. However, for females, the differences in initial earnings between I.E.K.s graduates and S.E. graduates converge for the remainder of their careers. Our findings do not support that post-secondary training might only be used as a screening device, except perhaps for females.

\section{Concluding remarks}

This paper tests both the «strong» version and the «weak» version of the screening hypothesis by using data on I.E.K.s and S.E. graduates. The empirical findings drive 
the concluding remarks. Firstly, in the public sector, the earnings profiles of the two groups are similar. Secondly, the initial earnings advantage of the vocational training degree holders compared with the control group is maintained at a constant level of approximately $5.76 \%$ throughout the employees' careers. The earnings advantage is slightly higher, especially for females, in the private sector compared with the public sector. Thirdly, using a Mincerian earnings function with a year of education or training and experience interaction term, no statistically significant convergence or divergence of the earnings profiles is detected in the private sector. Only for females is there a statistically weak convergence of the experience-earnings profiles. Therefore, the evidence shows that the «weak» version of screening hypothesis is valid only for females.

\section{References}

Albrecht, J. W. (1981). A procedure for testing the signalling hypothesis. Journal of Public Economics, $15,123-132$

Arabsheibani, G. (1989). The Wiles test revisited. Economics Letters, 29, 361-364

Arrow, K. J. (1973). Higher education as a filter. Journal of Public Economics, 2(3), 193-216

Becker, G. S. (1964). Human capital. New York: National Bureau of Economic Research

Becker, G. S. (1975). Human capital: A theoretical and empirical analysis, with special reference to education. Princeton: Princeton University Press

Bedard, K. (2001). Human capital versus signaling models: university access and high school dpopouts. Journal of Political Economy, 109, 749-775

Berg, I. (1971). Education and jobs: the great training robbery. New York: Preager

Brown, S. \& Sessions, J. (1999). Education and employment status: A test of the screening hypothesis for Italy. Economics of Education Review, 18, 397-404

Cohn, E., Kiker, B. \& De Oliveira, M. (1986). Further evidence on the screening hypothesis. Working Paper in Economics B-86-09. Columbia: University of South Carolina, College of Business Administration

Cohn, E., Kiker, B. \& De Oliveira, M. (1987). Further evidence on the screening hypothesis. Economics Letters, 25, 289-294

Fredland, J. E. \& Little, R. D. (1981). Self-employed workers: returns to education and training. Economic of Education Review, 1, 315-337

Groot, W. \& Oosterbeek, H. (1994). Earnings effects of different components of human capital vs screening. Review of Economics and Statistics, 76, 317-321

Hadjidema, S. (1998). Rates of return on higher education in Greece. Spoudai, 48(1-4)

Hadjidema, S. (1998). The higher education in Greece: measuring the benefits and costs. European Research Studies, 1(3), 5-18

Heywood, J. S. \& Wei, X. (2004). Education and the signalling hypothesis: evidence from a highly competitive labour market. Education Economics, 12 (1)

Katz, E. \& Ziderman, A. (1980). On education, screening and human capital. Economics Letters, 6, 81-88

Lambropoulos, H. (1992). Further evidence on the weak and strong versions of the screening hypothesis in Greece. Economics of Education Review, 11 (1), 61-65

Lambropoulos, H. \& Psacharopoulos, G. (1992). Educational expansion and earnings differentials in Greece. Comparative Education Review, 36 (1), 52-70

Layard, R. \& Psacharopoulos, G. (1974). The screening hypothesis and the returns to education. Journal of Political Economy, 82 (5), 985-988

Lee, K. H. (1980). Screening ability and the productivity of education in Malaysia. Economics Letter, 5 (2), 189-193

Li, F. L.; Ding, X. \& Morgan, W. John (2009). Higher Education and the starting wages of graduates of China. International Journal of Educational Development, 29, 374-381

Liu, P. W. \& Wong, Y. C. (1982). Educational screening by certificates: An empirical test. Economic Inquiry, 20 (1), 72-83 
Magoula, T. \& Psacharopoulos, G. (1999). Education and training and monetary rewards in Greece: An over-education false alarm. Applied Economics, 31 (December), 1589-1597

Miller, P. W. \& Volker, P. A. (1983). The screening hypothesis: An application of the Wiles test. Economic Inquiry, 22, 121-127

Miller, P.; Mulvey, C. \& Martin, N. (2004). A test of the sorting model of education in Australia. Economics of Education Review, 23(5), 473-482

Miler, P. (2009). The gender pay gap in the U.S.: does sector make a difference? Journal of Labor Research, 30(1), 52-74

Mincer, J. (1974). Schooling, experience and earnings. New York: Columbia University Press

Murphy, K. M. \& Welch, F. (1990). Empirical age earnings profiles. Journal of Labor Economics, 8(2), 202-29

Oosterbeek, H. (1992). Study duration and earnings: A test in relation to the human capital versus screening debate. Economics Letters, 40, 223-228

Psacharopoulos, G. (1979). On the weak versus the strong version of the screening hypothesis. Economics Letters, 4(2), 181-185

Psacharopoulos, G. (1983a). Education and private versus public sector pay. Labour and Society, 8(2), 123-134

Psacharopoulos, G. (1983b). Sex discrimination in the Greek labor market. Modern Greek Studies, 1(2), 339-358

Psacharopoulos, G. \& Tsamadias, C. (2001). Testing for screening using Vvocational skills: the case of Greece's technological institutes. Journal of Educational Planning and Administration, XV(4), 425-434

Psacharopoulos, G. \& Patrinos, H. A. (2002). Returns to investment in education. A further update. Washington: The World Bank

Riley, J. (1976). Information screening and human capital. The American Economic Review, 66(May), 254-260

Riley, J. (1979). Testing the educational screening hypothesis. Journal of Political Economy, 87(October), 227-252

Riley, J. (2001). Silver signals: twenty five years of screening and signaling. Journal of Economic Literature, 34, 432-478

Schultz, T. (1961). Investment in human capital. American Economic Review, 51, 1-17

Smith, A. (1911). An inquiry into the nature and causes of the wealth of nations. London: Dent

Spence, M. A. (1973). Job market signalling. Quarterly Journal Economics, 87(3), 355-374

Spence, M. A. (2002). Signalling in retrospect and the informational structure of markets. American Economic Review, 92(3), 434-459

Stiglitz, J. E. (1975). The theory of screening, education and the distribution of income. American Economic Review, 65(3), 283-300

Stiglitz, J. \& Weiss, A. (1995). Sorting out the differences between signalling and screening theories. In: M. Dempster (Eds.): Papers in commemoration of the mathematical economics seminar at Oxford University. Oxford: Oxford University Press

Taubman, P. \& Wales, T. (1973). Higher education, mental ability and screening. Journal of Political Economy, 81(1), 28-55

Tucker, I. B. (1985). Use of the decomposition technique to test the educational screening hypothesis. Economics of Education Review, 4(4), 321-326

Tucker, I. B. (1986). Evidence on the weak and the strong versions of the screening hypothesis in the United States. Economics Letters, 21(4), 391-394

Wiles, P. (1974). The correlation between education and earnings: the external-test-not-content hypothesis (ETNC). Higher Education, 3(1), 43-58

Willis, R. (1986). Wage determinants: A survey and re-interpretation of human capital earnings functions. In: O. Ashenfelter \& P. Laylard (Eds.): Handbook of Labor Economics, vol. 1. Amsterdam: Elsevier.

Wolpin, K. (1977). Education and screening. American Economic Review, 67(5), 949-958

Zairis, P. (1991). Sampling techniques. Athens: Rosis Publ,.

Ziderman, A. (1992). Evidence on screening: P-tests for Israel. Economics of Education Review, 11(1), $67-69$ 